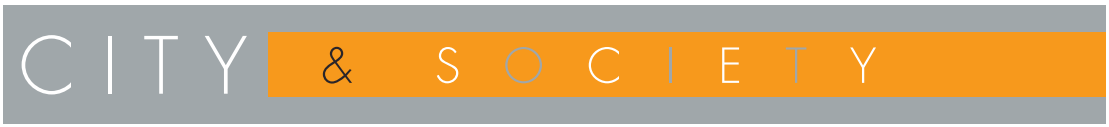

\title{
Prophetic Cosmopolitanism: Islam, Pop Psychology, and Civic Virtue in Indonesia
}

\author{
JAMES B. HOESTEREY \\ University of Michigan, Ann Arbor
}

\begin{abstract}
In contemporary Indonesia, a new generation of Muslim pop preachers and self-help gurus tap into, and trade on, the symbolic and economic capital of Islam, science, and media technologies. Through television sermons and elaborate Power Point presentations, these pop preachers and self-help gurus summon the Prophet Muhammad's life and teachings in ways that resonate with the civic concerns, consumerist desires, and aspirational piety of the Muslim middle classes. These sermons and seminars often portray the Prophet Muhammad as the ultimate measure of what it means to be cosmopolitan. In this article I explore "prophetic cosmopolitanism" as a vernacular Muslim cosmopolitanism, but one which is not isolated from, or necessarily prior to, Western liberal-secular ideas about civic virtue. I argue instead that prophetic cosmopolitanism is both informed by, and offered as an alternative to, global discourses about psychology and self, citizen and believer, nation and umma. [Cosmopolitanism, Islam, popular culture, public sphere, transnationalism].
\end{abstract}

What is the sign of "humanness" in the category of the transnational "cosmopolitan"? Where does the subject of global inquiry or injury stand or speak from? To what does it bear relation; from where does it claim responsibility?

Homi K. Bhabha, "Unsatisfied: Notes on Vernacular Cosmopolitanism"

\footnotetext{
\rceil he global Islamic revival of the last several decades has fragmented traditional forms of religious authority, generated new figures of public piety, and created new publics (and counter-publics) through which Islamic teachings are constituted and contested throughout the so-called Muslim world (Eickelman and Piscatori r 996; Eickelman and Anderson 2003; Göle 2002; Hirschkind 2001). Among these new public voices were not just Muslim intellectuals, but also a generation of pop culture prophets - artists, televangelists, and corporate trainers who also claim to speak for Islam. Several scholars have noted the remarkable rise of Egyptian television preacher Amr Khaled who, clad in business jacket and sprinkling his sermons with self-help slogans, embodies a new kind of middle class Muslim chic (Wise 2003; Bayat 2007). In contemporary Indonesia-amidst an expanding (and consuming) middle class, the relaxing of restrictions placed on Islamic media following Suharto's authoritarian regime (1965-1998), and a massive proliferation and privatization of media - a new generation of pop preachers and Muslim 
"trainers" now tap into, and trade on, the symbolic and economic capital of Islam, science, and media technologies (Hoesterey 2008; Howell 2007; Rudnyckyj 2009a).

Islamic training seminars in Indonesia, especially popular among the aspiring middle classes, have become religio-civic forums through which issues of civic virtue and Muslim citizenship are constituted and contested. Similar to Charles Hirschkind's description of cassette sermons as propagation $\left(d a^{\prime} w a\right)$ in Cairo, Islamic training seminars in Indonesia

provided conceptual resources grounded in a long tradition of Islamic practice and scholarly inquiry, [yet] these resources were put to novel uses within a contemporary situation shaped by modern political institutions, pedagogical techniques, and media forms, as well as by notions of civic responsibility grounded in the idea and experience of national citizenship (Hirschkind 200 I:I I).

Muslim trainers and self-help gurus in Indonesia, through books, sermons, and seminars, psychologized the civic virtues of the Prophet Muhammad. Through elaborate Power Point presentations in the ballrooms of five-star hotels, they summoned the Prophet Muhammad's life and teachings in ways that resonated with the civic concerns, consumerist desires, and aspirational piety of the Muslim middle classes. One of these popular preachers cum spiritual trainer and self-help guru, Ustad M. Hamdani Adz Dzaky, coined the phrase "prophetic intelligence" to claim that the Prophet Muhammad was not only the exemplar of Western Psychology's I.Q. and E.Q. (emotional intelligence), but more importantly, the Prophet Muhammad also embodied "S.Q." (spiritual quotient). Ustad Hamdani led an Islamic boarding school in central Java, trained corporate managers in the capital of Jakarta, and published his scientific data in the Indonesian academic journal, Jurnal Psikologi Islami (established in 2005). Like most of his colleagues on the Islamic training circuit, Hamdani portrayed the Prophet Muhammad as the embodiment of an Islamic psychology of civic virtue.

By the early 200os, Islamic popular psychology, what proponents term Psikologi Islami, had become the leading category in Indonesia's burgeoning publishing industry (Watson 2005). M. Syafi'i Antonio, in his best-selling book, Muhammad SAW, Super Leader Super Manager describes Muhammad's successful career as a trader, for which he was known as al-amin (the trustworthy). Another Muslim trainer articulates the Prophet Muhammad's example in terms of the Myers-Briggs personality matrix, in which the Prophet is described as Muhammad, ESFJ (Extrovert, Sensing, Feeling, Judgment). In this article I explore how these Muslim self-help gurus re-calibrate the prophetic tradition through a transnational language of popular psychology and management theory that summons both the religious authority of the prophetic tradition and the purportedly scientific merits of Psikologi Islami. During televised sermons and Islamic training seminars, they articulate a moral

Muslim trainers and self-help gurus in Indonesia, through books, sermons, and seminars, psychologized the civic virtues of the

Prophet

Muhammad 
model of cosmopolitan citizenship based on Islamic ethics and transnational psychology. In doing so, these pop preachers and trainers transform a seventh-century prophet into a modern cosmopolitan, a citizen-believer who is committed to Islam and tolerant of difference. By summoning the psycho-civic dimensions of the Prophet Muhammad, this "indigenous" Islamic psychology provides a model for Muslim cosmopolitanism. I will argue, however, that the indigeneity of both Psikologi Islami and Muslim cosmopolitanism is actually produced through, not completely distinct from, a religio-scientific engagement with so-called "Western" psychology.

Historian of religion Anna Gade has recently observed similar shifts in representations of the Prophet Muhammad in contemporary Indonesia:

Now, under accelerating conditions of global capitalism and worldwide Islamic awakening, new types of texts circulate in regional context that have both Muslim and non-Muslim origins; and, more importantly, they may even seek to blend (or blur) the boundaries among these systems. [...] [The] very understanding of the figure of the Prophet Muhammad himself and his life story may now be imagined entirely in terms of inspiring connection over distance and difference (2010:272).

The historical genealogies of Psikologi Islami in contemporary Indonesia can be traced back not only to religious biography, but also to colonial psychiatry and the nationalist struggle. The production of psychiatric knowledge figured prominently in the logics of empire and the lore of the anti-colonial struggle in Indonesia (and elsewhere throughout the colonized world, e.g. Fanon 1963). In the Dutch East Indies during the early $20^{\text {th }}$ century, Indonesian nationalist psychiatrists articulated an indigenous Javanese psychology to counter Dutch colonial psychiatry's ideas about the so-called "native mind" and the supposedly "lazy native" (Pols 2007). Proponents of Psikologi Islami in post-authoritarian Indonesia, as "subjects of global inquiry and injury" (Bhabha 1996), were markedly different from nationalist Indonesian psychiatrists who sought to re-claim the "Javanese personality" from Dutch psychiatry. As "subjects of injury," they summoned the legacy of the Prophet Muhammad to rectify what they perceived as the "moral crisis" and marginalization of Islam during Suharto's authoritarian rule (1965-1998). And as "subjects of inquiry," they turned to global pop psychology—not through postcolonial mimetic desire, but as a way to argue that the Prophet Muhammad was the ultimate exemplar of civic virtue.

In light of these hybrid psycho-biographical accounts of the Prophet Muhammad, I pose some questions: What might a Muslim cosmopolitan look like? Or, to summon Homi Bhabha's term, how vernacular is "vernacular cosmopolitanism"? I explore the religious, psychological, and civic contours of what I refer to as "prophetic cosmopolitanism." I understand prophetic cosmopolitanism as vernacular only insofar as it contributes to Islamic traditions and conversations-in different places, spaces, and historical moments-about the civic life and ethical example of the Prophet Muhammad. My use of this term, and my focus on biographical 
accounts that psychologize the Prophet Muhammad, is not intended to describe a vernacular cosmopolitanism that stands completely apart from Western understandings of psychology and citizenship. Prophetic cosmopolitanism is inspired by, in dialogue with, even rupturing and revising, the pop psychology of the so-called West. ${ }^{r}$ As Bruce Lawrence has observed, "cosmopolitans are neither local nor global but both simultaneously" (2010:315-16). A vernacular Muslim cosmopolitanism, then, can be at once both inspired by, and in opposition to, Western understandings of science, self, and citizenship. As I will argue, prophetic cosmopolitanism in contemporary Indonesia appeals to the worldliness of global psychological discourses and the moral example of the Prophet, yet it does not necessarily entail a commitment towards the liberal ideals of global citizenship and religious pluralism.

In what follows I describe how cosmopolitanism has been framed by political philosophers and social scientists, consider how the prophetic tradition is summoned as a psycho-civic ideal, and suggest how an inquiry into prophetic cosmopolitanism opens up the analytical and conceptual space for comparative and interdisciplinary work on Islamic publics and civic ethics. I also explore several articulations of the Prophet Muhammad in terms of traditions of prophetic veneration in Islam as well as the social, political, and economic context of post-authoritarian democratic Indonesia. After positioning this project within academic literatures on cosmopolitanism and Islamic publics, I turn my attention towards the pop culture portrayals of the Prophet Muhammad within the market niche of Islamic self-help and civic training seminars. I examine the civic volunteer training sessions for celebrity preacher Abdullah Gymnastiar's moral movement, the "Movement to Build the Conscience of the Nation" (or, the Indonesian acronym Gema Nusa). I describe how pop preachers and self-help gurus conjure an Islamic psychology that casts the Prophet Muhammad as the ultimate exemplar of civic virtue and cosmopolitan citizenship. Lastly, I consider a different sort of Islamic civic training, promoted by the Indonesian branch of Hizbut Tahrir, a transnational Islamist organization that aspires for a global Islamicate. ${ }^{2}$ I note that Hizbut Tahrir's civic training seminars also draw from transnational pop psychology and the prophetic tradition as a way to assert a decidedly different vision of cosmopolitanism which, although committed to tolerance and nonviolence, also espouses a Muslim cosmopolitanism that does not necessarily aspire to liberal-secular versions of religious pluralism and universal identity.

\section{Cosmopolitanisms, anthropology, and the problem of identity}

The prophetic tradition is summoned as a psycho-civic ideal

\footnotetext{
$\Lambda \mathrm{y}$ inquiry into Muslim cosmopolitanism engages and builds on inter-disciplinary conversations about cosmopolitanism, its meanings, uses, and Others. Political philosopher Martha Nussbaum ( I994) proposed a model of cosmopolitan identity
} 
characterized by multiple, hierarchical allegiances to local culture, the nation-state, and global citizenship. This Kantian, neo-Enlightenment articulation of citizens of the world assumes that proper, rational cosmopolitans define themselves in terms of the outermost concentric circle of identity which, ideally, should supersede affective allegiances to nation, religion, or ethnicity. Scholars from several disciplines have challenged this model of static and hierarchical levels of belonging. For example, Mark Goodale seeks to move the discussion about cosmopolitanism beyond issues of identity politics and multiple levels of allegiance:

Although this concentric circle approach to identity is perhaps analytically convenient, it cannot begin to capture the complexity of identity formation in Bolivia, or anywhere else for that matter. ... These different dimensions of identity cannot be parsed into hierarchically related constituent parts; this is not how people experience themselves in the world (2006:64I).

In a variant of Bhabha's "vernacular cosmopolitanism" (r996) and Appiah's "rooted cosmopolitanism" (2005), Goodale offers the idea of "indigenous cosmopolitanism" as an alternative understanding that goes beyond identity and place:

what indigenous cosmopolitanism in Bolivia demonstrates is that a cosmos, projected anew as a new and more expansive framework of essential inclusion, can be both translocal and transnational and nonglobal and nonuniversal at the same time (ibid:640-4I; see also Delugan 2010; Werbner 2008; Strathern and Stewart 2010; Robinson 2007).

Seen from this perspective, Nussbaum's concentric circles of identity are re-imagined as loosely interlocking Venn diagrams of fluctuating allegiances not easily reduced to local ethnicity or global identity.

Muslim cosmopolitanism, as an indigenous or vernacular form, can actually bypass questions of identity. The forms of colonial mimicry that so intrigued postcolonial theorists have given way to new sorts of cultural borrowing in which language, knowledge, and religious traditions, not just identity, define not only what a cosmopolitan should be, but also what a cosmopolitan should know, and towards what a cosmopolitan should aspire. To this end, my understanding of prophetic cosmopolitanism as a psycho-religious language of discourse and learning is inspired by the work of historian Muhammad Qasim Zaman, who provides an insightful portrayal of Ibn Battuta, the itinerant Islamic scholar often summoned by many Islamicists as the pre-modern cosmopolitan figure par excellence:

it suggests, as does Ibn Battuta's career as a whole, the existence and efficacy of a shared and longstanding language of discourse and learning, of shared ideas about what constituted valuable knowledge and how such knowledge was articulated, preserved, and transmitted. [. . .] 
What we have here is a language that seeks multiple audiences, an intelligibility across local cultures (2005:84, I02).

In Zaman's description, identity was rather marginal to the cultural and religious work of Ibn Battuta's cosmopolitanism. Instead, what allowed Ibn Battuta to settle into his new post in faraway Delhi was a "valuable knowledge," a language about that knowledge, and an aspiration for intelligibility across local worlds.

In the context of contemporary Indonesia, Muslim trainers and pop preachers promote psikologi Islami as a "valuable knowledge" through which Muslims can imagine and emulate the Prophet Muhammad as the ultimate exemplar of civic virtue and cosmopolitan citizenship. Combining the prophetic tradition with global discourses of psychology, these trainers re-assert the legacy of civic vitue in Islamic history. Joel Kahn provides a similar portrait of Muslim cosmopolitanism among aspiring middle-class Muslims in neighboring Malaysia:

the new Malaysian Muslim is global in outlook, hostile to tradition in all its guises, universalizing in aspiration, favourably disposed to entrepreneurship, the accumulation of wealth and conspicuous consumption, and generally very comfortable with the latest technology.... [This] raises the questions, therefore, of whether this new 'globalised' Islam might constitute an alternative to so-called Western and/or secular forms of cosmopolitan governance, the terms of the coalition among the diverse groups which make up national (or world) society being now somehow derived from the universal principles of Islam itself (2008:265).

I build on Kahn's idea that Islam provides alternative versions of cosmopolitanism. Indonesia's pop preachers and trainers articulate a version of cosmopolitanism that is part of a wider engagement with, selective borrowing from, and subsequent revision of both Western popular psychology and Sufi treatises on the heart (see also Howell 2007). In this case, the vernacular emerges in the re-mediation of religious texts and transnational psychology through which enduring traditions of religious biography are given contemporary expression and meaning. As David Novak cogently observes with respect to the global flow of Bollywood cinema,

culture is produced anew in these "foreign takes" on popular media, in which acts of cultural borrowing channel emergent forms of cosmopolitan subjectivity. ... Remediation reveals and constitutes contemporary cosmopolitanism (2010:40,63).

Turning to the prophetic tradition as a site of remediation (not as static biography but as re-imagined life history) offers an understanding of Muslim cosmopolitanism in which the vernacular is constituted through the reappropriation of global ideas about psychology and civic virtue. 
In the final section, I offer a cautionary note concerning the ways in which (and assumptions upon which) some academics now classify certain people as un-cosmopolitan. Appiah's notion of "rooted cosmopolitanism" was a welcome corrective to Nussbaum's insistence on the outermost concentric circle of global citizenship. However, I argue that Appiah's more recent foray into the possibilities of Muslim cosmopolitanism (Appiah 2006) is more problematic, resting on an uncritical embrace of Olivier Roy's ideas about the purported "failure of political Islam" (Roy 2004; cited in Appiah 2006:I37-I43). Like Roy, Appiah is enamored by the possibility of a "post-Islamist" identity (Lawrence 20I:323n.r6) which, as the argument goes, contrasts sharply with the radicalized fringe of "neo-fundamentalists," whom Appiah refers to as "counter-cosmopolitans":

What distinguishes the neofundamentalists, violent or not, is that they exemplify the possibility of a kind of universal ethics that inverts the picture of cosmopolitanism I've been elaborating. Universalism without toleration, it's clear, turns easily into murder (2006:140).

How might

academics speak

about Muslim

cosmopolitanism

in ways that do

not re-inscribe

colonial categories

of modernity and

civilization or "good Muslims" and "bad Muslims"?
To his credit, Appiah acknowledges "competing universalities" (2006:143-147), yet his analysis leaves little room for competing cosmopolitanisms, those that might not aspire to global citizenship, secular political identity, or equal claims to religious truth. How might academics speak about Muslim cosmopolitanism in ways that do not re-inscribe colonial categories of modernity and civilization or "good Muslims" and "bad Muslims"? Katherine Ewing offers similar caution and raises questions about cosmopolitanism as a category of academic inquiry:

[Appiah] defines the cosmopolitan in a way that explicitly excludes the "neofundamentalist," thereby marking the fundamentalist as the cosmopolitan's other. [...] Could it be that, with the concept of cosmopolitanism, scholars are seeking to find a way to perpetuate this discursive structure, now that neither modernity nor modernism convincingly distinguishes "us" and "them"? [...] Within the past few years, and especially since 9/I I, "cosmopolitanism" has emerged as an analytic category that in some respects has supplanted the modern as a way of characterizing a progressive subjectivity (2010:53).

Likewise, I will argue that Muslim trainers for the Indonesian branch of the transnational organization Hizbut Tahrir, far from Appiah's "countercosmopolitans," incorporate global pop psychology and modern modes of reflexivity in their efforts to craft a Muslim cosmopolitanism that is not compatible with Appiah and Roy's preference for post-Islamist democratic citizenship. Contrary to Appiah's description of countercosmopolitans who believe in universalism without toleration, I will suggest that Muslim trainers in Hizbut Tahrir Indonesia articulate a 
language and form of cosmopolitanism that aspires for civic tolerance, but without religious universalism.

\section{Marketing Muhammad: pop Islam and the prophetic tradition in Indonesia}

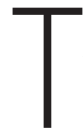
he consumption and public display of Islamic brands and products have become increasingly important avenues through which aspiring middle-class Muslims across the globe search for meaning and express piety. Scholars studying Islam in Indonesia have provided insightful accounts of pop Islam phenomena, including: Islam-themed novels and films (Widodo 2008; Hassan 2009); Islamic fashion and aspirations of class mobility (Jones 2007); self-proclaimed "sexologists" (Smith-Hefner 2009); the rise and fall of celebrity preachers and their personal brands (Hoesterey 2008); New Age Sufi networks among urban elites (Howell 2007); and Muslim "spiritual trainers” (Rudnyckyj 2009a). As Greg Fealy has observed,

Much of this religious expression is taking a commodified form, in which Muslims selectively consume "Islamic" products from an expanding spiritual marketplace rather than following the settled patterns of behaviour of their parents and grandparents (2008:16).

In response to these socio-religious shifts, some scholars of Islam have begun to ask questions about the relationship between Islam, economy, and the religious marketplace of modernity, what Haenni (2006) and Rudnyckyj (2009b) refer to as "market Islam."

A new generation of Muslim self-help gurus, who often lack conventional credentials in religious education, garnered novel forms of religious authority through the re-appropriation of Western psychology, an adept use of media technologies, and the shrewd ability to market themselves as the embodiment of Islamic modernity. Pop preacher cum self-help guru Abdullah Gymnastiar was among Indonesia's most visible pop icons of public piety and Muslim modernity. Known belovedly throughout Indonesia as "Aa Gym" (elder brother Gym), he promoted his Islamic pop psychology "Manajemen Qolbu" (Heart Management) through televised sermons, social media, best-selling books, and corporate training seminars. Gymnastiar offered Manajemen Qolbu, a hybrid of Western pop psychology and Sufi ideas of the heart, as an Islamic corrective to secular understandings of personal affect and public ethics. When I began fieldwork at his Islamic school and business complex in 2005, Gymnastiar was at the pinnacle of his popularity, preaching to stadium crowds by day and dining with religious, political, and business elite by night. Over the course of two years, I followed Gymnastiar on the Islamic self-help circuit, where he frequently shared the stage with other spiritual trainers and self-help gurus. Gymnastiar often summoned (and employed) these trainers to 
participate in his campaigns for religious outreach, public piety, and civic volunteer training.

Gymnastiar's preaching emphasized particular moments of the Prophet Muhammad's life and career. For example, when he spoke about Muhammad's entrepreneurial endeavors, Gymnastiar urged Muslims to learn from a closer understanding of the Prophet as an ethical trader who, years prior to receiving revelations, was bestowed the title al-amin (the trustworthy). In 2005 Gymnastiar and his training department designed the corporate seminar, "Business from the Perspective of Islam.” In 2007 Gymnastiar preached about (and posted for his virtual community) his treatise on the "Entrepreneurship of the Prophet Muhammad."3 Gymnastiar offers a life history of the Prophet Muhammad that speaks to broader issues of Islamic ethics and a spirit of capitalism. Importantly, he does so through the language of management theory and pop psychology:

As it turns out, in our studies of the Prophet Muhammad there is an era of his life that we seldom talk about, namely how Muhammad became a profesional. ${ }^{4}$ The Prophet is proof that when [one] possesses the spirit of an entrepreneur, then [that person] will be capable of managing anything. At the age of six Muhammad was already an orphan, with no one to rely on. [...] It was at that moment when the young, small Muhammad began to tend to/herd his own goats, [i.e.] made his own living. Imagine, when the Prophet was twelve years old, his uncle invited him along to Syria, which was thousands of kilometers away. When he returned from that trip, he frequently engaged in trade and business. In fact, a young profesional named Muhammad had become well-known throughout the Arabian peninsula. Subhanallah ("Glorious is God"). [. . .] After that he was able to become a rich person without any financial capital. The capital that the Prophet possessed was that he was al-amin, or his reputation as trustworthy. Beginning now we must take steps to become trustworthy throughout our lives.

In Gymnastiar's account, Muhammad was not just a prophet; he was a profesional, an entrepreneur whose piety, trustworthiness, and selfinitiative yielded great prosperity. Similar to Gymnastiar's own life story, the moral of the story is that Muhammad went from rags to riches (and you can too!). The framing of Muhammad as a profesional denotes a certain worldly and entrepreneurial sensibility. In Gymnastiar's sermons, it is the figure of Muhammad as worldly, ethical trader, who achieved great honor and recognition during business expeditions to foreign lands, that defines him as cosmopolitan.

The prophetic tradition was frequently summoned by other trainers and self-help gurus. In 2007 Gymnastiar's close friend and colleague, Dr. M. Syafi'i Antonio, published the best-selling book, Muhammad: Super Manager, Super Leader. ${ }^{5}$ Born Nio Gwan Chung, Antonio changed his Chinese-Indonesian name when he converted to Islam. He later attended the University of Jordan, studied at Cairo's Al-Azhar University, obtained a Master's degree in economics at University of Malaysia, 
and then earned his doctorate at University of Melbourne. Dr. Antonio later founded the first Indonesian university that awards degrees in both Western and Islamic finance. Many Indonesians subscribed to Antonio's daily text messages for business success (for a price, of course) and joined training seminars at his "Prophetic Leadership and Management Center." The promotional blurb of Antonio's book reminds readers that the Prophet Muhammad is the best role model for business success:

Learn leadership and management intelligence from the best role model in self development, business and entrepreneurship, family life, propagation, the social and political order, the legal system, education, and military strategy.

Other pop preachers and trainers who endorsed the book include: Ary Ginanjar (founder of Islamic training program ESQ, Emotional Spiritual Quotient); Arifin Ilham and Yusuf Mansur (popular television preachers); and Hermawan Kartajaya (marketing guru and co-author of the popular financial self-help book, Syariah Marketing). Collectively, their voices reflect an emerging class of Muslim reformers who, as "figures of Indonesian modernity" (Barker, Lindquist et al. 2009), hover between religious teacher, human resources consultant, and life coach. In the acknowledgments section, Antonio writes that he:

owes a debt of gratitude to those senior dai (one who calls people to Islam) and young agents of change like brother Ary Ginanjar Agustian and K.H. Abdullah Gymnastiar, ustadz (religious teacher) Muhammad Arifin Ilham, ustadz Yusuf Mansur and akhi (brother) Jeffry al-Bukhari who, from time to time, exchange ideas about propagation strategies and hold events together (2007:iv).

These figures of pop Islam-preachers and trainers-appear together in Antonio's acknowledgments, united by their common mission for dakwah (propagation), the market niche of Islamic self-help seminars, and their appropriation of transnational pop psychology and management theory. They claim to represent the revolutionary "cutting edge" of Islam, to which they often refer in their promotional materials as "Islam mutakhir." This idea of being cutting edge, something more than modern, provides the market appeal for their psycho-religious formulas for success. And, for them, the Prophet Muhammad is the most mutakhir of all. Like Gymnastiar, Antonio tells the story of how the Prophet embodied a particular psycho-ethical disposition deemed necessary for selfdevelopment, personal leadership, and entrepreneurship:

After Abdul Muthalib passed away Muhammad was cared for by his uncle Abu Talib. The young Muhammad frequently had to help with his uncle's family finances by doing hard work for the people of Mecca. Such experiences of his youth became psychological capital (modal psikologis) for when he became an entrepreneur in the future (2007:78-79).

Antonio tells the story of how the

Prophet embodied

a particular

psycho-ethical

disposition deemed

necessary for

self-development,

personal

leadership, and

entrepreneurship 
Antonio stresses the importance of this "psychological capital," what he understands as the product of self-discovery. Advocating modern modes of introspection and reflexivity, he professes that "the essence of leadership is recognizing, discovering, and identifying one's real self" (2007:7 I; original English in italics). Antonio then suggests that religious practice and ethical self-discipline can facilitate this process of self discovery:

In the teachings of Islam, this can be carried out through meditations on God (dzikr), recitations of God's names, prayer, contemplative reflection (tafakkur), and fasting. The wisdom (hikmah) obtained [from these] ... includes identifying one's total self, calming one's emotions (ibid).

According to Antonio's "steps to peak performance," prayer, recitation, introspection, and fasting are the necessary first steps of self-discovery and, ultimately, lead one towards their "peak potential." Real leadership, according to Antonio, "is a way of thinking, feeling, and functioning, a way of life and a way of being that is transformative" (ibid; original English in italics). Then, shifting psycho-religious registers, Antonio summons the words of the Prophet Muhammad, "Ibda' bi nafsik!" (begin with yourself!). In this world of Islamic self-help in Indonesia, Muhammad's legacy as moral exemplar is thus imagined in terms of psycho-religious disposition that is commensurate with the modern notion of an introspective, self-enterprising self.

\section{Muhammad, ESFJ: prophetic psychology and civic virtue}

n September 2004, from the steps of the Indonesian national monument in Jakarta, Gymnastiar and several prominent religious leaders and politicians declared the civic movement "Gema Nusa," or the "Movement to Build the Conscience of the Nation." During my fieldwork I met with hundreds of Gema Nusa volunteers, participated in both national and regional civic volunteer training programs, and attended the official declarations of local Gema Nusa branches in the provinces of North Sumatra, West Sumatra, Southern Kalimantan, and South Sulawesi. Along the way, I interviewed people at every level from the executive board members who procured operational funding to the "civic volunteers" (sukarelawan) who provided food and water for earthquake and tsunami victims. Approximately four million people across the archipelago signed-up to be Gema Nusa volunteers within the first months of its founding. The executive board subsequently decided to formulate civic volunteer training courses. In my fieldwork, I certainly did not find any distinctive subject-position that we might call Muslim cosmopolitan. Instead, Gema Nusa "civic volunteers" were citizen-believers who felt overlapping, and, at times discrepant, degrees of affinity and inclusion between ethnicity, nation, and umma. 
During the planning sessions for the Gema Nusa "Training of Trainers," the executive board decided to devote 70 percent of the training curriculum to human management theory and 30 percent to the concept of civic voluntarism (kesukarelawanan). Further, they invited popular Muslim trainers and human resources consultants (not preachers and clerics) to educate a generation of Gema Nusa trainers who would subsequently train local volunteers in provincial offices throughout Indonesia. ${ }^{7}$ Despite the widespread popularity of Muslim trainers in Indonesia, it is important to note that they have not eclipsed the religious authority of orthodox religious scholars and intellectuals. Instead, trainers carved out their own niche of psycho-religious knowledge and everyday wisdom. The session titles provide a glimpse into how they frame civic virtue in terms of Islamic self-help psychology: The Spirit of Struggle; A Trainer's Mentality of Success; Achieving Greatness; A Structural Profile of Gema Nusa; Knowing Oneself; Work Ethic; Managing Training Sessions, A to Z; Developing Local Branches; Motivation and Team-Building; and Voluntarism.

On April 2 I, 2006 Gema Nusa leaders from over thirty provinces across the archipelago gathered in Jakarta for the "Training of Trainers" seminar (TOT). ${ }^{8}$ A sense of anticipation and palpable excitement filled the auditorium as Gema Nusa trainees arrived, registered, and took their seats for the opening ceremony. Generally speaking, the province-level Gema Nusa leaders who attended the TOT were the field volunteers, not Gema Nusa's wealthy financiers who often enjoyed lavish dinners with Gymnastiar and his entourage of political, business, and religious elite. Those who attended the TOT represented the grass roots level of civic volunteers who were genuinely concerned with what they described as Indonesia's "moral crisis." Many were pleased to be in the orbit of a celebrity preacher, but very few stood to gain any significant political or economic advantage from such association. The TOT trainers, on the other hand, were among Gymnastiar's advisors and consultants and many served on the Gema Nusa executive board.

At the opening ceremonies Gymnastiar donned a Gema Nusa baseball cap, specially designed in the red and white colors of the Indonesian flag. The ceremonies began with the Indonesian national anthem, which was solemnly revered by Gymnastiar, the son of a military father. Gymnastiar was committed to the global Muslim community, the umma, but he was decidedly nationalist and admittedly skeptical about the political pragmatism of a global Islamicate.

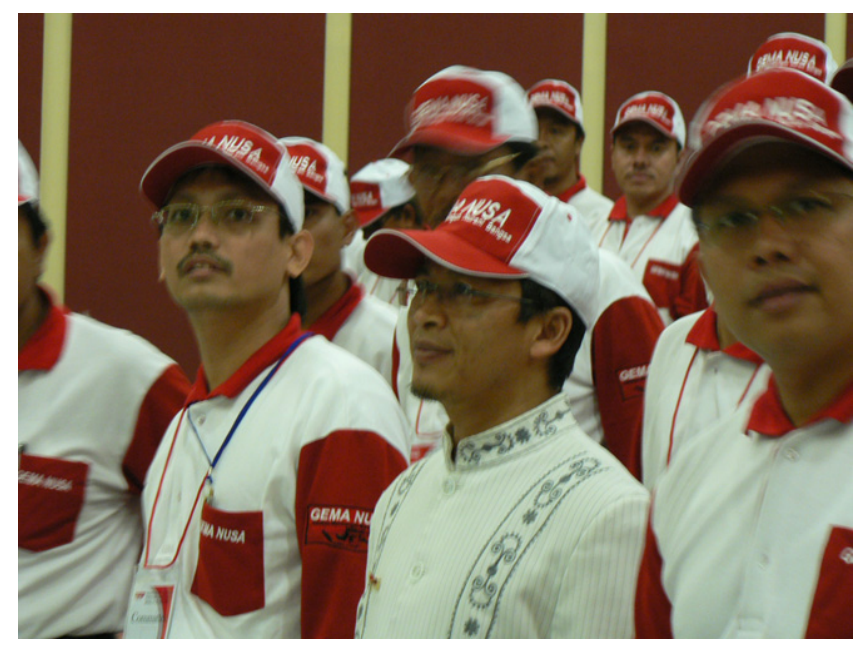

Figure I. Training of Trainers opening ceremonies. Gymnastiar (middle); Naufal Ismail, trainer and Gema Nusa board member (left) and Mukhlis Yusuf, a marketing strategist, trainer, and board member (right). Photo by author. 
He was also popular among non-Muslims in Indonesia. During a time of inter-religious turmoil in Central Sulawesi, Gymnastiar went to a Christian church in the town of Poso to preach patience, tolerance, and restraint. For Gymnastiar, civic virtue was not necessarily Islamic. He looked to the Prophet Muhammad as the ideal ethical citizen, yet Gymnastiar also valorized the heroes and volunteers of Indonesia's nationalist struggle. During his nostalgic opening remarks, titled "The Spirit of Struggle," Gymnastiar recollected the independence movement:

Indonesia's freedom was won by volunteers who struggled for the freedom we Indonesians now enjoy ... their efforts did not abide by "office hours," and they did not expect wages or anything in return. Their struggle was sincere ... And so now we, too, must take notice, feel a sense of concern, do something, and struggle onward to improve the moral crisis in Indonesia.

Moral change can only occur, he told the audience, through each individual taking the personal initiative to become a good moral example, a suri teladan. Gymnastiar told the participants that Gema Nusa was not a political movement to critique others' immorality; instead Gema Nusa was a moral movement to inspire personal transformation. Speaking in terms of the "conscience of the nation," Gymnastiar translated Sufi moral philosophy into the lay terms of pop psychology. Gema Nusa would be the microcosm and, as the theory goes, collective reform would follow:

We must begin with ourselves. In the Qur'an, it is written that we must not order others to do something before we have first ordered ourselves. And so it is with national moral reform. Remember my "3 M's": Mulai (begin) with yourself; Mulai with small things; Mulai right now . . . . . .] Volunteers must become a good model of morality ... the way to change the nation is to begin by changing individuals ... and the way to change individuals is through their conscience... So, don't think about others before you first consider and know yourself ... we do this through education and training. [...] Remember the story of the Prophet Muhammad, peace be upon him. Once, when someone had urinated in the mosque and people became angry, the Prophet simply said calmly, 'Fetch water and clean it up.' Similarly, volunteers should help, not just judge others. [. . .] We must transform antagonistic relations into friendship. Our country has many religions and Gema Nusa should transcend religious divides. What is important is faithful service [. . .] We must remember the lessons of the Prophet Muhammad ... the leader of a group must also serve that group.

According to Gymnastiar, self-knowledge and ethical discipline are the keys to cosmopolitan civic virtue. After the opening ceremonies Gymnastiar departed for Saudi Arabia as celebrity host for an umroh pilgrimage, leaving everything in the hands of his trusted trainers, who played an especially important role in Gymnastiar's vision of moral and political transformation. Importantly, the TOT trainees were not just learning to 
be good civic volunteers; they would become the trainers who would educate local volunteers in their province. In what follows I introduce three Gema Nusa trainers and describe how each summons global psychological discourses to craft a legacy of the Prophet Muhammad as the exemplar of civic virtue.

Naufal Mahfudz Ismail received a Master's degree in human resources in Japan and works as director of human resources for a stateowned company. He also serves on Gema Nusa's executive board, where he advises on human resources, recruitment issues, and volunteer training. I first met Ismail during a Gema Nusa executive board meeting in October 2005, when he outlined the human resources strategies for the recruitment and management of the volunteers. Our paths crossed again several months later at the "Spiritual Capital" seminar organized by Taufik Bahaudin, a business management professor at University of Indonesia and author of the organizational psychology book Brainware Management (Bahaudin I999). That seminar featured special guest Danah Zohar, an American corporate consultant and author of several books translated into Indonesian, including Spiritual Intelligence and Spiritual Capital. The founder of ESQ (Emotional Spiritual Quotient) training, Ary Ginanjar, was among the VIP guests at the seminar. ${ }^{9}$ Ismail himself was a proud alumnus of ESQ training and was quite pleased to mingle with Ginanjar on that day.

Ismail's mission for the Gema Nusa "Training of Trainers," he told me, was to teach trainees how an understanding of organizational and personality psychology could enhance the bureaucratic and human resources aspects necessary to mobilize civic volunteers. ${ }^{\text {I० }} \mathrm{He}$ began the session "Know Thyself" by summoning Western pop psychology and management theory: "According to a Harvard study, and I forget the exact name of the researcher, 85 percent of one's success depends on soft competency." The allusion to Harvard, despite its lack of specific scholars

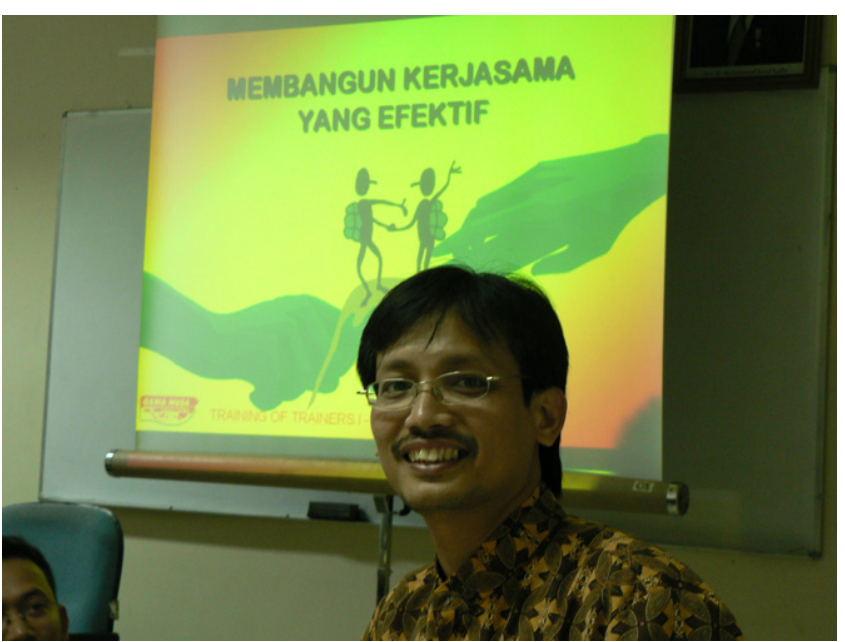

Figure 2. Gema Nusa trainer Naufal Ismail. Power Point reads: Building Effective Teamwork. Photo by author. or studies, provided a sense of techno-scientific authority. Ismail went on to suggest that each Gema Nusa branch office must identify the various personality strengths and "core competencies" of its leaders and members. According to Ismail, the Myers-Briggs personality test was an especially useful way to identify these personality strengths and "core competencies." After a polished Power Point presentation where he explained the history of personality theory in Western psychology, Ismail introduced the Myers-Briggs personality test and explained the sixteen possible profiles. 
Following Naufal's presentation, each trainee completed the translated Myers-Briggs questionnaire and calculated their personality profile. Naufal emphasized that these categories are indicators of general tendencies and that people often fall in the middle of the continuum or even change during their lifetime. Once again, the Prophet Muhammad was the measure:

For example the Prophet Muhammad, peace be upon him, over the course of his lifetime he shifted from an extrovert towards more of an introvert. The important thing to remember is that, in your local Gema Nusa branches, different personality types can accomplish different things. There must be synergy in Gema Nusa. We want to become a Super Team, not Superman.

Pak Arif, a rector at a respected university, raised his hand and chimed in, "we should really be contemplating the personality profile of the Prophet Muhammad. It seems that this research is based on Western concepts, not necessarily including Muslims." Ismail replied enthusiastically, "Absolutely. The ultimate example is the Prophet Muhammad," he said, once again sprinkling his language with English words. "If we think about the Prophet Muhammad, peace be upon him, we could say that he best resembles an ESFJ_Extrovert, Sensing, Feeling, Judging." An ESFJ, Ismail tells us, represents the "servant leader"- the leader whose duty is to serve the people. Trainers and trainees thus re-imagined the Prophet Muhammad as virtuous citizen through the language of transnational psychology.

Another Gema Nusa trainer, Jamil Azzaini, was more popular than Ismail on the Islamic training circuit and national political stage. Azzaini preaches the benefits of spiritual intelligence in the workplace, writes a regular advice column in the Islamic newspaper Republika, hosts a corporate radio program on Trijaya FM, and serves on the executive board for the national board of Islamic charity. Azzaini hosted corporate training seminars for private companies and state-owned enterprises throughout Indonesia and also led seminars in Singapore, Malaysia, Hong Kong,

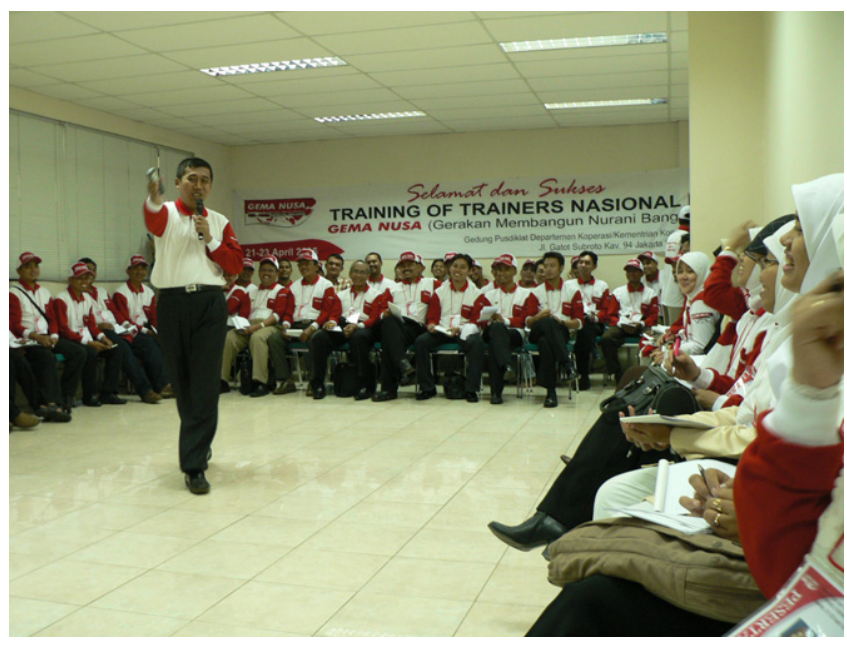

Figure 3. Jamil Azzaini training Gema Nusa volunteers. Photo by author. and the Philippines. Azzaini and colleagues, in their best-selling book Kubik Leadership, argue for the need to create synergy among the multiple kinds of intelligence-a synergy they call "valence." His most recent book, God, Here is My Life Proposal, was another bestseller and serves as the basis for his new training seminars. Not easily classified as nationalist or Islamist, Azzaini served on Gema Nusa's board, but also appeared as a featured guest speaker during a Hizbut Tahrir rally for an international caliphate. 
Azzaini is known more as a motivator and trainer than a preacher, yet he frequently gives sermons at mosques and prayer groups during Ramadan and also works as celebrity tour guide for umroh and hajj pilgrimage tours. Whereas some public announcements tout his educational credentials in engineering with a master's in business management (Ir. Jamil Azzaini, M.M.), elsewhere Azzaini is given the honorable Arabic-Indonesian title of religious teacher, "Ustad Jamil Azzaini." These multiple registers provide further evidence that the figure of the trainer hovers between psychologist and religious teacher. Azzaini led the first day of training with the session, "The Mentality of a Successful Trainer." Once again, cosmopolitan virtue was defined in terms of prophetic psychology:

In the words of the Prophet Muhammad, peace be upon him, 'whoever is better today than yesterday is fortunate; whoever is the same today as yesterday is unfortunate; whoever is worse today than yesterday is calamitous.' [. . .] The key to improvement is that we must not be afraid to fail.

The courage to fail, Azzaini continued, means that we must be brave enough to move out of our "comfort zone." Azzaini explicitly draws from pop psychology theories of "neuro-linguistic programming," which has roots in the American New Age movement of the I970s and is increasingly popular in Indonesia under the acronym "NLP." For Azzaini, success is an issue of mind over matter. After telling inspirational stories about the unrelenting courage of Helen Keller and Lance Armstrong, Azzaini tried to motivate trainees through an historical analogy about the spread of Islam into southern Europe:

Remember the story of Thoriq bin Ziyad. He had just crossed the Mediterranean and landed at Gibraltar with his 7,000 troops. And what did he do? He ordered that the ships be burned! With that single act, his troops knew that there was nowhere to run-only sea behind them and enemy troops ahead. Out-numbered by an overwhelming margin, there was nothing left but to charge ahead in battle... we must emulate the bravery of Thoriq bin Ziyad, the willingness to go beyond our comfort zone and rid ourselves of the fear of failing.

Such conquests in the name of righteousness, Azzaini told us, require a certain synergy between the various forms of intelligence, what he calls "valensi." As he later told me, one of his goals for volunteer training was to encourage this synergistic approach to psycho-religious intelligence and human resources management. Ever the Islamic marketer, Azzaini invited trainees to learn more by reading his book Kubik Leadership, in which he summoned the expertise of both Western science and psikologi Islami to explain the connections between cognitive intelligence (IQ), emotional intelligence (EQ), and spiritual intelligence (SQ):

Based on research from Harvard University and California University, we know that IQ only accounts for 6 perccent of our intelligence. The 
key to valensi is to find a way to productively connect each of our intelligences with each other. Spiritual intelligence must be part of our lives, at home and at work. Prayer and fasting is not enough. [.. .] EQ and SQ are dominant, so we must not leave out God. And remember that the Prophet Muhammad had extraordinary EQ.

Gema Nusa civic training thus recalibrates the prophetic tradition by portraying the Prophet Muhammad as the embodiment of emotional intelligence. According to Azzaini, EQ is an important quality of civic virtue. Similar to Ismail, Azzaini does not cite specific authors of these studies; rather, he summons the perceived legitimacy of psychology and renowned institutions of higher education. For Azzaini and many other Muslim trainers in Indonesia, it does not matter whether or not they are borrowing the phrase "emotional intelligence" (popularized by American psychologist Daniel Goleman). ${ }^{11}$ As spiritual trainers, what matters to them is their assertion that the Prophet Muhammad is the ultimate exemplar of emotional and spiritual intelligence.

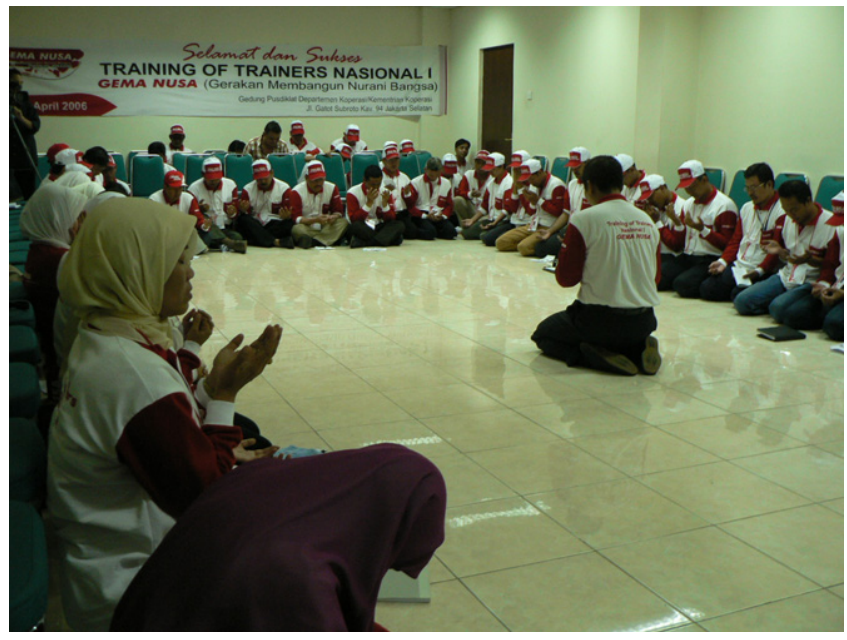

Figure 4. Azzaini leading trainees in supplication to God. Photo by author.

As Azzaini brought the session to a close, he dimmed the lights and asked trainees to envision themselves meeting with the Prophet Muhammad. In a soft, gentle voice Azzaini asked trainees what they would say to the Prophet about how they used their Godgiven talents? How, Azzaini asked, had they cultivated their EQ and SQ to improve their country? Softly sobbing by the end of his supplication, he wondered whether his own civic good deeds would be enough on the day of reckoning.

\section{Counter-cosmopolitanism? Languages of cosmopolitanism, limits of universalism}

\footnotetext{
ema Nusa is a trans-religious organization, whose advisory board 7 includes prominent officials from each of the officially recognized religions in Indonesia. Framed in nationalist terms, the "-sa" of the acronym Gema Nusa signifies the bangsa, the people of Indonesia. The uniforms were the red and white of the beloved national flag-consciously not the color green which often denotes Islam in Indonesia. However, ideas of pluralism and cosmopolitanism among some Gema Nusa volunteers were also marked by an ambivalence in which civic engagement did not necessarily aspire towards universalism, at least not if that meant conceding the truth claims of every religion as equal. One Gema Nusa trainee characterized this ambivalent, almost begrudg-
} 
ing, sense of pluralist civic-mindedness in a recent Facebook posting about a Christian national holiday: "Today I'm red and white. Tomorrow back to green." Contrary to Appiah's characterization of so-called "counter-cosmopolitans" who promote universalism without tolerance, this example suggests tolerance without universalism. In this final section, I am interested in how Hizbut Tahrir trainers, at least in Indonesia, appeal to the form and content of pop psychology to project a notion of cosmopolitanism that does not fit easily into liberal-secular notions of civic virtue and religious pluralism. To explore this point further, I now turn to one Gema Nusa trainer who appealed to the global language of pop psychology, but also conjured the prophetic tradition to promote civic virtue within the context of an Islamic caliphate.

M. Karebet Widjajakusuma, Jamil Azzaini's colleague at a management consulting firm, was asked to substitute for a trainer who was unable to attend. Widjajakusuma is another well-known author and trainer who earns a lucrative salary blending Islamic ethics, pop psychology, and business management. The title of Widjajakusuma's 2007 self-help book, Be the Best, Not "Be Asa," is an Indonesian-English play on words that could be translated as "Be the Best, Not Average." He co-authored his first book, Designing Islamic Business, with M. Ismail Yusanto, the spokesperson for Indonesia's branch of Hizbut Tahrir. Widjajakusuma also leads training sessions as part of Hizbut Tahrir's outreach and propagation. Characteristic of his published books, Widjajakusuma's applies management theory in order to create, in his words, an "Islamic management orientation" for Hizbut Tahrir. In one of his Power Point slide below, the graphics begin with the word "People" left of the arrow, then proceed to describe the mix of strategic organization, production, marketing, finance, and human resources development that will lead to material profits, non-material benefit, sustainable growth, and, most importantly, Allah's blessings.

When the entire Gema Nusa TOT Power Point curriculum was burned to CDs for province-level training seminars, Widjajakusuma uploaded additional Power Point files from his Hizbut Tahrir training sessions that were not part of the Gema Nusa curriculum. These Hizbut Tahrir Indonesia presentations summon Western management theory at the same time as they build an argument that liberal-secular democracy is akin to the "trap of a monitor lizard." One of Widjajakusuma's Power Point slide below portrays the monitor lizard, laying in wait, baiting its victims with the allure of industrial capitalism and free sex.

Another Hizbut Tahrir seminar, "Training for Political Islam," draws from the language of human resources development to describe the psychological and ethical discipline of politically-active Muslims. As detailed in one slide, "Self Management" consists of "knowing one's potential, actualizing one's competence, and cultivating one's emotions." Later in the presentation, these keys to civic virtue are juxtaposed with sayings of the Prophet Muhammad that exalt "the pious few" and decry "the many" - used by Widjajakusuma to glorify the caliphate and to caution against the moral peril of majority rule. Although his political 
aspiration is towards an Islamic state, Widjajakusuma also seeks to fashion a cosmopolitan Muslim self through the language of Islamic psychology and the example of the Prophet Muhammad. In Widjajakusuma's understanding, however, there is little that is democratic or pluralist in the legacy of the Prophet.

I would argue that Hizbut Tahrir trainers such as Widjajakusuma, who claim a certain cosmopolitanism by appealing to global pop psychology yet also aspire toward a global Islamicate, cannot easily be defined as intolerant or "counter-cosmopolitan." Katherine Ewing makes a similar point in her research about Turkish Muslims in Germany:

[...] under the guise of rejection of certain aspects of Western practice ... there is actually an incitement within many Islamist and other fundamentalist groups to modernize, through an array of practices that constitute a modern subject, which can be characterized by a reflexive, self-conscious interiority, a sense of rupture with a traditional past, and a global, even cosmopolitan, orientation (2010:53).

Widjajakusuma looks to the prophetic tradition for inspiration, authority, and authenticity. For him, as with other Muslim trainers in Indonesia, the Prophet Muhammad provides the model for how to respect, tolerate, and administrate non-Muslims. Yet, this version of prophetic cosmopolitanism does not often aspire to universalist identity or religious pluralism. Like many conservative Muslim leaders in Indonesia, Widjajakusuma differentiates "theological pluralism" (pluralisme), which would cede that all religious truth claims are equal, from the demographic sense of "sociological pluralism" (pluralitas). In his Hizbut Tahrir Indonesia training, Widjajakusuma quotes a saying from the Prophet urging suspicion towards Christians and Jews. Widjajakusuma even uses the image of the eye located on the back of the American dollar bill (designed to repeatedly blink during the presentation) to support his theory of a Western conspiracy against Islam. Although the figure of the trainer possesses some sort of redemptive quality in the public imagination of contemporary Indonesia, these Hizbut Tahrir training materials suggest that there is nothing inherently democratic or pluralist about spiritual trainers or their versions of prophetic cosmopolitanism. That is not to say, however, that Hizbut Tahrir trainers are "counter-cosmopolitan."

\section{Conclusions: the "cutting-edge" of cosmopolitanism}

n contemporary Indonesia, competing cosmopolitanisms, with divergent claims to tolerance and universalism, each summon the perceived authority of global pop psychology and human management theory. Prophetic cosmopolitanism, as I have described it here, does not map out an interior cosmopolitan subjectivity. Instead, I offer the term as a methodological (and potentially comparative) approach to understand how Muslim cosmopolitanism is constituted and contested 

Prophet to help promote particular visions of citizenship and civic duty. When viewed within the historical traditions of the veneration of the Prophet Muhammad, prophetic cosmopolitanism might be understood as a genre of Muslim cosmopolitanism, not its vernacular. It is not some Javanese folk Islam separate from, or prior to, Western liberal-secular ideas about civic virtue; on the contrary, prophetic cosmopolitanism in contemporary Indonesia is both informed by, and offered as an alternative to, global discourses about psychology and self, citizen and believer, nation and umma. Much like the indigenous Bolivian leaders described by Goodale (2006:464), pop preachers and spiritual trainers do not simply try to vernacularize modernity - they seek to reclaim modernity with the Prophet Muhammad as the measure of civic virtue and cosmopolitan citizenship.

Similar to other consumerist styles of self-fashioning in Indonesian pop Islam, current articulations of prophetic cosmopolitanism (and the pop psychology on which it rests) will likely lose their appeal in Indonesia's religious marketplace of Islamic modernity. As Muhammad Qasim Zaman reminds us, languages of cosmopolitanism come in and out of vogue and are subject to local political conditions: "Ibn Battuta's reception at Delhi is thus not an expression of a timeless, reified Islamic cosmopolitanism but something that is better situated at the meeting point of his own ambitions and a sultan's political agenda" (Zaman 2005:88). Just as Abdullah Gymnastiar claimed to be telling a heretofore neglected part of the Prophet's life history, the quest for the cutting edge, the mutakhir, of Islam will likely generate new renditions of prophetic cosmopolitanism in years to come. Indeed, the oncebeloved Gymnastiar eventually fell from public grace in Indonesia, and the sense of Islamic training programs like ESQ as "cutting edge" has begun to fade. ${ }^{12}$ Whereas styles of self-fashioning and icons of public piety may be ephemeral, the importance of the prophetic tradition endures. Exactly what prophetic cosmopolitanism might look like in the future in Indonesia and elsewhere will depend on how Muslims imagine, summon, and emulate the civic virtues of the Prophet Muhammad.

\section{Notes}

Acknowledgments. I would like to thank Mara L. Leichtman, Dorothea Schulz, Bruce Lawrence and the anonymous reviewers for City $\mathbb{E}$ Society for their generous engagement and critical reflections. I would also like to thank the Andrew W. Mellon Foundation, and American Council for Learned Societies (ACLS) for support during the writing and revising of this article.

'Likewise, "Western" psychology has multiple, global genealogies. Some of the New Age psychology popular in Indonesia (such as Tolly Burkan's "Firewalking training") were themselves inspired by Orientalist fantasies of "Eastern" religious tradition (Danforth I989).

Spiritual trainers

in Indonesia

conjure specific

stories and sayings

of the Prophet to

help promote

particular visions

of citizenship and civic duty 
${ }^{2}$ See Mandaville (2007) for a discussion of the roots, context, and transnational networks of Hizbut Tahrir.

3"Entrepreneurship Rasulullah." Posted on cybermq.com on September 28, 2007. Accessed October 3, 2007. See also Gymnastiar 2006.

${ }^{4}$ Gymnastiar used the Indonesianized version of the English word "professional." Several self-help gurus related to me that using English words made their programs more appealing to clients. Seminars that began with "The Power of ..." and "The Secrets of ..." tended to sell better than those exclusively in Indonesian.

${ }^{5}$ Note that these English words are used in the original title.

${ }^{6}$ Gerakan Membangun Nurani Bangsa. Gema Nusa is the abbreviated phrase.

'The local training sessions were called Pembina Nurani, or "The Cultivation of Conscience."

${ }^{8}$ The phrase "Training of Trainers" or "TOT," has become part of a widely-used Human Resources Development lexicon in Indonesia.

${ }^{9}$ During that seminar Zohar critiqued Bahaudin's cognitive, bio-medical understanding of the brain. Interestingly, it was Ary Ginanjar, not Bahaudin, whom Zohar invited for an international symposium at Oxford University. Several months later, Ginanjar and Zohar hosted an "East Meets West" seminar in Jakarta. Approximately I, ooo seats were available, most priced well over $\$$ Ioo per ticket.

${ }^{10}$ Other prominent public figures, not considered "trainers" per se, presented material for the thirty percent of the training sessions that addressed the concept of voluntarism: Ahmad Mukhlis Yusuf, Gema Nusa executive chairperson (and current CEO of the state-owned Antara news agency), led a session about Gema Nusa's bureaucratic structure and five-year plan; Teguh Juwarno, former news anchor and advisor to the Minister of Education, spoke about how local Gema Nusa branches could cooperate with news media to promote their social agenda; and Anas Urbandingnum, the rising star and current chair of the Democrat Party, led a discussion about civic voluntarism as a form of national development.

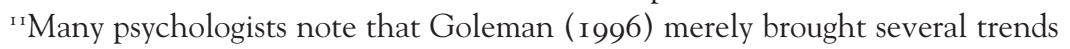
in the psychological study of emotion to a broad public audience (with the help of Oprah Winfrey). With respect to pop psychology discourses in Indonesia, I am less interested in genealogies of knowledge than the ways in which trainers draw on its legitimacy in efforts to garner authority and to encourage civic virtue.

${ }^{\mathrm{I}}$ The ethnographic data in this article portray Gymnastiar at the pinnacle of his popularity. In December 2006, less than a year after the Gema Nusa training described here, Gymnastiar fell from public grace when his female admirers learned that he secretly married a second wife. Feeling betrayed by Gymnastiar's public image as a loving husband, they launched a campaign to boycott his sermons and training seminars. In recent years Gymnastiar has made a modest comeback. Notwithstanding the importance of what Gymnastiar's rise, fall, and comeback campaign says about popular Islam and public ethics (Hoesterey 2008), here I focus mostly on other trainers who remain very popular on both the public stage and the self-help circuit.

\section{References Cited}

\section{Antonio, Muhammad Syafi'i}

2007 Muhammad SAW: The Super Leader Super Manager. Jakarta: Prophetic Leadership and Management Centre.

Appiah, Kwame Anthony

2006 Cosmopolitanism: Ethics in a World of Strangers. New York: W.W. Norton.

2005 The Ethics of Identity. Princeton: Princeton University Press. 
Bahaudin, Taufik

I999 Brainware Management: Generasi kelima Manajemen Manusia [Brainware

Management: The Fifth Generation of People Management]. Jakarta: Gramedia.

Barker, Joshua, Johan Lindquist, with Tom Boellstorff, Chris Brown, Aryo Danusiri, Dadi Darmadi, Sheri Gibbings, Jesse Grayman, James Hoesterey, Carla Jones, Doreen Lee, Daromir Rudnyckyj, Rachel Silvey, and Karen Strassler 2009 Figures of Indonesian Modernity. Indonesia 87:35-72.

Bayat, Asef 2007 Making Islam Democratic: Social Movements and the Post-Islamist Turn. Stanford: Stanford University Press.

Bhabha, Homi K.

I 996 Unsatisfied: Notes on Vernacular Cosmopolitanism. In Text and Nation: Cross Disciplinary Essays on Cultural and National Identities. Laura Garcia-Moreno and Peter Pfeiffer, eds. Pp.I9i-207. Columbia, SC: Camden House.

Danforth, Loring M.

I989 Firewalking and Religious Healing: The Anastenaria of Greece and the American Firewalking Movement. Princeton: Princeton University Press.

Delugan, Robin Maria 2010 Indigeneity across Borders: Hemispheric Migrations and Cosmopolitan Encounters. American Ethnologist 37( I):83-97.

Eickelman, Dale F. and Jon W. Anderson, eds. 2003 New Media in the Muslim World: the Emerging Public Sphere. Bloomington, IN: Indiana University Press.

Eickelman, Dale F. and James P. Piscatori I 996 Muslim Politics. Princeton, NJ: Princeton University Press.

Ewing, Katherine Pratt 2010 The Misrecognition of a Modern Islamist organization: Germany Faces "Fundamentalism." In Rethinking Islamic Studies. Carl Ernst and Richard Martin, eds. Pp.52-71. Columbia: University of South Carolina Press.

Fanon, Frantz I963 The Wretched of the Earth. New York: Grove Press.

Fealy, Greg 2008 Consuming Islam: Commodified religion and Aspirational Pietism in Contemporary Indonesia. In Expressing Islam: Religious Life and Politics in Indonesia. Sally White and Greg Fealy, eds. Pp.I5-39. Singapore: Institute of Southeast Asian Studies.

Gade, Anna M.

2010 Religious Biography of the Prophet Muhammad in Twenty-First-Century Indonesia." In The Cambridge Companion to Muhammad. Jonathan Brockopp, ed. Pp.25I-273. Cambridge: Cambridge University Press.

Göle, Nilüfer

2002 Islam in Public: New Visibilities and New Imaginaries. Public Culture (14) I: I 73-90.

Goleman, Daniel

I996 Emotional Intelligence: Why it Can Matter More than IQ. New York: Bantam Books.

Goodale, Mark

2006 Reclaiming Modernity: Indigenous Cosmopolitanism and the Coming of the Second Revolution in Bolivia. American Ethnologist 33(4):634-49.

Gymnastiar, Abdullah

2007 Entrepreneurship Rasulullah. www.cybermq.com 28 Sept 2007. Accessed 3

Oct 2007 . 
2006 Saya Tidak Ingin Kaya Tapi Harus Kaya [I Do Not Want to be Rich But I

Have to be Rich]. Bandung: MQS.

Haenni, Patrick

2006 L'Islam de Marché: L’Autre Révolution Conservative. Paris: Le Seuil/La

République des Idées.

Hassan, Noorhaidi

2009 The Making of Public Islam: Piety, Agency, and Commodification on the

Landscape of the Indonesian Public Sphere. Contemporary Islam 3:229-50.

Hirschkind, Charles

200 I Civic Virtue and Religious Reason: An Islamic Counterpublic. Cultural

Anthropology I6(I):3-34.

Hoesterey, James B.

2008 Marketing Morality: The Rise, Fall, and Re-branding of Aa Gym." In

Expressing Islam: Religious Life and Politics in Indonesia. Greg Fealy and

Sally White, eds. Pp.95-I I 2. Singapore: Institute of Southeast Asian Studies.

Howell, Julia Day

2007 Modernity and Islamic Spirituality in Indonesia's New Sufi Networks." In

Sufism and the "Modern" in Islam. Martin van Bruinessen and Julia Day

Howell, eds. Pp.2 I 7-240. London: IB Tauris.

Jones, Carla

2007 Fashion and Faith in Urban Indonesia. Fashion Theory I I (2/3):2 I I-32.

Kahn, Joel S.

2008 Other Cosmopolitanisms in the Making of the Modern Malay World. In

Anthropology and the New Cosmopolitanism. Pnina Werbner, ed. Pp.26I280. New York: Berg.

Lawrence, Bruce

2010 Afterword: Competing Genealogies of Muslim cosmopolitanism. In

Rethinking Islamic Studies. Carl Ernst and Richard Martin, eds. Pp.302-324.

Columbia: University of South Carolina Press.

Mandaville, Peter

2007 Global Political Islam. New York: Routledge.

Novak, David

2010 Cosmopolitanism, Remediation, and the Ghost World of Bollywood. Cultural Anthropology 25(I):40-72.

Nussbaum, Martha

I 994 Patriotism and Cosmopolitanism. The Boston Review XIX:5.

Pols, Hans

2007 The Nature of the Native Mind: Contested Views of Dutch Colonial Psychiatrists in the former Dutch East Indies. In Psychiatry and Empire. Sloan

Mahone and Megan Vaughan, eds. Pp. 172-196. Cambridge: Cambridge University Press.

Robinson, Kathryn, ed.

2007 Asian and Pacific Cosmopolitans: Self and Subject in Motion. New York:

Palgrave.

Roy, Olivier

2004 Globalized Islam. New York: Columbia University Press.

Rudnyckyj, Daromir

2009a Spiritual Trainer. In Figures of Indonesian modernity." Indonesia 87:

43-45.

2009 b Market Islam in Indonesia. Journal of the Royal Anthropological Institute

I 5 (N.S.): I $82-200$.

Smith-Hefner, Nancy

2009 "Hypersexed" Youth and the New Muslim Sexology in Java, Indonesia.

Review of Indonesian and Malaysian Affairs 43(I):209-244. 
Strathern, Andrew and Pamela J. Stewart

20I0 Shifting Centres, Tense Peripheries: Indigenous Cosmopolitanisms. In United in Discontent. Dimitrios Theodossopoulos and Elisabeth Kirtsoglou, eds. Pp.20-44. New York: Berghahn.

Watson, C. W.

2005 Islamic Books and Their Publishers: Notes on the Contemporary Indonesian Scene. Journal of Islamic Studies r6(2): I 77-2 I0.

Werbner, Pnina, ed.

2008 Anthropology and the New Cosmopolitanism. Oxford and New York: Berg.

Widodo, Amrih

2008 Writing for God: Piety and Consumption in Popular Islam. Inside Indonesia 93 (Aug-Oct)

Wise, Lindsay

2003 Words from the Heart: New Forms of Islamic Preaching in Egypt.” M. Phil thesis, St. Anthony's College. Oxford: Oxford University.

Zaman, Muhammad Qasim

2005 The Scope and Limits of Islamic Cosmopolitanism and the Discursive Language of the "Ulama." In Muslim Networks: From Hajj to Hip Hop. miriam cooke and Bruce Lawrence, eds. Pp.84-104. Chapel Hill: University of North Carolina Press. 